\title{
Effect of Ginger (Zingiber Officinale) and Garlic (Allium Sativum) On the Performance, Haematology and Serum Biochemical Indices of Laying Hens
}

\author{
Olawale Mojeed Akanbi ${ }^{1,2 *}$, Grace Osejemen Aigbogun ${ }^{2}$ and Johnson A Oluponna ${ }^{2}$ \\ ${ }^{1}$ The Federal University of Technology Akure, Nigeria \\ ${ }^{2}$ Federal college of Animal Health and Production Technology, Moor plantation, Ibadan, Nigeria
}

*Corresponding author: Akanbi Olawale Mojeed, Department of Animal Health and Production, Federal University of Technology Akure, Nigeria.

Received Date: February 05, 2020

Published Date: February 18, 2020

\begin{abstract}
Every animal is as good as what it eats so the availability of good poultry nutrition is crucial to the improvement of poultry products. The competition between humans and the domestic fowl for some feedstuffs greatly hampers the production of quality meat and eggs. This competition affects the relative availability and affordability of the basic feed ingredients used in poultry nutrition. The study was carried out to evaluate the effect of ginger (Zingiber officinale) and garlic (Allium sativum) on the performance, hematology and serum indices of laying hens. The research was carried out at the National Cereal research Institute experimental farm, Moor Plantation, Ibadan where seventy-two points of lay hens were randomly allotted into six dietary treatments of 12 birds per treatment in a Completely Randomized Design. The diets were formulated to contain $0 \%$ ginger and $0 \%$ garlic, $1 \%$ ginger and $1 \%$ garlic, $2 \%$ ginger and $2 \%$ garlic, $3 \%$ ginger and $3 \%$ garlic, $3 \%$ ginger and $0 \%$ garlic, and $0 \%$ ginger and $3 \%$ garlic to represented treatments 1,2,3,4,5 and 6 respectively. Significant differences $(p<0.05)$ were observed in performance which includes weight gain, feed conversion ratio and hen day production. There were significant $(\mathrm{p}<0.05)$ influences in the haematology and serum indices such as Packed cell volume, red blood cell, haemoglobin, white blood cell, mean cell volume, mean corpuscular haemoglobin concentration, while there were no significant differences in the cholesterol in the serum. The results of the haematology shows that the immunity increased, which is an indication that the spices (ginger and garlic) are good sources of vitamins and minerals and the inclusion of ginger and garlic at $2 \%$ ginger and $2 \%$ garlic can be fed to laying hens without detrimental effect on the performance and health of the birds.
\end{abstract}

Keywords: Garlic; Ginger; Haematology; Performance; Serum

Abbreviations: FCR: Feed conversion ratio; PCV: Packed cell volume; WBC: White blood cell; LDL: Low density lipoprotein; MCV: Mean cell volume; MCHC: Mean corpuscular haemoglobin concentration.

\section{Introduction}

The importance of animals for human beings cannot be overemphasized. This is because animal proteins are better consumed than plant proteins. According to [1], feeding of low protein diets to broilers resulted in increased in abdominal fat deposition. Thus, efforts are being made to remodel poultry feeding indices to accommodate the challenges of competition, cost and production of nutritious poultry products. Recently, researches have become more focused on the use of naturally occurring phytobiotics in replacing chemically based additives and drugs [2]. Some phytogenic feed additives have been successfully incorporated into the feeding standard of poultry birds without any deleterious effect or toxic residues [3]. Furthermore, they reported that there are several naturally existing medicinal plants which could be used in preventing the accumulation of lipids; fats and cholesterol. Prominent among these plants are garlic, turmeric and ginger. [4] reported that several studies have identified the separate use of these plants but, there is the dearth of information on the combined therapeutic effect of ginger and garlic. However, the combined effect can be to prevent high blood pressure, high 
cholesterol level and cholesterol oxidation which are the primary causes of atherosclerosis, the precursor of cardiovascular diseases. [5] also reported that ginger contains volatile oils like borneol, camphene, Citral, eucalyptol, Linalool, phellandrene, zingiberene, zingiberol (gingerol, zingerone and shogaol) and resin. The research was therefore geared to evaluate the in vivo effect of feeding ginger and garlic to laying hens.

\section{Materials and Method}

\section{Experimental site}

The research was carried out at the National Cereal Research Institute (NCRI) experimental farm, Moor Plantation, Apata, Ibadan. The acclimatization of the birds was carried out for 4 weeks and the experiment was carried out for 8 weeks.

\section{Pen preparation}

The pen was designed for an experimental purpose and battery cages were used for the research. The pen was washed and cleaned 2 weeks before the arrival of the birds and was also disinfected.

\section{Collection and processing of ginger and garlic}

Freshly harvested ginger and garlic were purchased from Oje market, Ibadan. They were sun dried for 7 days to reduce the moisture content and the possible phytochemicals that could hinder the availability of the nutrients to the birds. Thereafter, it was ground and milled into a powder prior to inclusion to other feed ingredients.

\section{Experimental birds and management}

Seventy-two points of lay Isa brown layers were procured from a reputable farm in Ibadan and were fed grower's mash for 4-week acclimatization before the commencement of the experiment. They were allotted into 6 dietary treatment formulated to contain $0 \%$ ginger and $0 \%$ garlic, $1 \%$ ginger and $1 \%$ garlic, $2 \%$ ginger and $2 \%$ garlic, $3 \%$ ginger and $3 \%$ garlic, $3 \%$ ginger and $0 \%$ garlic, and $0 \%$ ginger and 3\% garlic to represented treatments $1,2,3,4,5$ and 6 respectively as shown in Table 1 . The experiment was conducted in a Completely Randomized Design (CRD) using 4 birds in a replicate of 6 treatments.

Table 1: Gross composition of experimental diets.

\begin{tabular}{|c|c|c|c|c|c|c|}
\hline Ingredients (\%) & Diet 1 & Diet 2 & Diet 3 & Diet 4 & Diet 5 & Diet 6 \\
\hline Maize & 34.15 & 34.15 & 34.15 & 34.15 & 34.15 & 34.15 \\
\hline Soyabean Meal & 8.53 & 8.53 & 8.53 & 8.53 & 8.53 & 8.53 \\
\hline Maize Bran & 12 & 11.7 & 11.5 & 10 & 11 & 11.4 \\
\hline Wheat Bran & 20 & 18.7 & 17.55 & 16.9 & 19 & 19 \\
\hline Palm Kernel cake & 14.9 & 14.5 & 14.3 & 14 & 13.9 & 13.5 \\
\hline Groundnut Cake & 6 & 6 & 6 & 6 & 6 & 6 \\
\hline Bone Meal & 1.5 & 1.5 & 1.5 & 1.5 & 1.5 & 1.5 \\
\hline Limestone & 2.5 & 2.5 & 2.5 & 2.5 & 2.5 & 2.5 \\
\hline Salt & 0.25 & 0.25 & 0.25 & 0.25 & 0.25 & 0.25 \\
\hline Premix & 0.25 & 0.25 & 0.25 & 0.25 & 0.25 & 0.25 \\
\hline Methionine & 0.1 & 0.1 & 0.1 & 0.1 & 0.1 & 0.1 \\
\hline Lysine & 0.16 & 0.16 & 0.16 & 0.16 & 0.16 & 0.16 \\
\hline Ginger & 0 & 1 & 2 & 3 & 3 & 0 \\
\hline Garlic & 0 & 1 & 2 & 3 & 0 & 3 \\
\hline Calculated & Analysis & & & & & \\
\hline Protein & 16.83 & 16.14 & 16.1 & 16.07 & 16.03 & 15.97 \\
\hline M.E (Kcal/kg) & 2735.8 & 2735 & 2724 & 2709.44 & 2702.29 & 2700.75 \\
\hline
\end{tabular}

Diet 1: $0 \%$ ginger and $0 \%$ garlic, Diet 2: $1 \%$ ginger and $1 \%$ garlic, Diet 3: $2 \%$ ginger and $2 \%$ garlic, Die $4: 3 \%$ ginger and $3 \%$ garlic, Diet $5: 3 \%$ ginger and $0 \%$ garlic, diet $6: 0 \%$ ginger and $3 \%$ garlic

\section{Data collection}

Data were collected on the average daily feed intake, average daily weight gain, and feed conversion ratio and hen day production.

Average daily feed intake: The daily feed intake was derived by subtracting the left over from the actual quantity fed and this was done on a daily basis. The amount of feed taken by the end of the week was added and divided by 7 and the numbers of birds per treatment, this will give the reframe amount consumed by a bird/ day. 
Average daily weight gain: The weekly weight gain was derived subtracting with the initial weight recorded before the commencement of the experiment. The final weight gain was therefore derived and divided by numbers of hens per treatment.

Feed conversion ratio: The feed conversion ratio was determined to know how the feed has been utilized and is determined by dividing the feed intake overweight gain.

Hen-day production: This is the numbers of eggs produced per layer during the period of lay. This was determined by dividing the number of the egg laid by the number of hens and days multiplied by 100 .

$$
\text { The formula: } \frac{\text { Number of the egg laid }}{\text { Number of hen } \times \text { days }} \times 100
$$

Blood collection: At the end of the experiment, six birds were bled per replicate through the jugular vein and bottle containing anticoagulant (EDTA bottle) and a bottle not containing anticoagulant for serum and placed in a slanted form and analyzed at the Department of Livestock Science Laboratory, Institute of Agricultural Research and Training, Moor Plantation, Ibadan for haematological and serum biochemical analysis.

\section{Statistical analysis}

Data generated were subjected to analysis of variance of SPSS 17. The means were separated using the New Duncan Multiple Range Test (DMRT) [6].

\section{Results}

The result obtained from the performance characteristics of the experimental birds is presented in Table 2 which shows that there were significant $(\mathrm{p}<0.05)$ differences in all treatments and $\mathrm{T}_{5}$ recording highest average weight gain of $0.10 \mathrm{~g}$ and $\mathrm{T}_{4}$ with the lowest value of $0.00 \mathrm{~g} . \mathrm{T}_{2}$ recorded the highest value for average daily feed intake with $108.70 \mathrm{~g}$ and the lowest value recorded for $\mathrm{T}_{5}$ (102.71g). The best feed conversion ratio was obtained in $\mathrm{T}_{6}$ with 0.02 while $\mathrm{T}_{1}$ recorded the highest hen day production and not significantly ( $\mathrm{p}>0.05$ ) different from $\mathrm{T}_{2}$ and $\mathrm{T}_{3} . \mathrm{T}_{4}$ and $\mathrm{T}_{6}$ recorded the lowest hen day production. Table 3 revealed the haematological parameters of the birds. Haematology indices reflect the effects of dietary treatment of the hens to meet physiological, biochemical and metabolic necessities [7]. In this study, there were significant differences $(\mathrm{p}<0.05)$ in all parameters recorded. Birds in $\mathrm{T}_{6}$ recorded the highest Packed Cell Volume (PCV) of 34.59\% and is significantly different $(\mathrm{p}<0.05)$ from other treatments with $\mathrm{T}_{1}$ having the lowest value of $30.20 \%$. There was a significant difference in the $\mathrm{RBC}$ with $\mathrm{T}_{5}$ recording the highest value of $3.67 \times 106 \mathrm{l} / \mu \mathrm{m}$ and closely followed by $\mathrm{T}_{6}(3.66 \times 106 \mathrm{l} / \mu \mathrm{m})$ while $\mathrm{T}_{1}$ recorded lowest statistical value of $2.27 \times 106 \mathrm{l} / \mu \mathrm{m}$. the haemoglobin and white blood cell (WBC) was also highest in $\mathrm{T}_{6}$ with $41.83 \mathrm{~g} / \mathrm{dl}$ and $8.36 \mathrm{mg} / \mathrm{dl}$ respectively and significant $(\mathrm{p}>0.05)$ influence of ginger and garlic was recorded (Table 3 ).

Table 2: Performance characteristics of laying hens fed varied inclusion levels of ginger and garlic.

\begin{tabular}{|c|c|c|c|c|c|c|c|}
\hline Parameters & Diet 1 & Diet 2 & Diet 3 & Diet 4 & Diet 5 & Diet 6 & SEM ( \pm ) \\
\hline A. Initial Wgt (kg/bird) & 1.4 & 1.37 & 1.34 & 1.34 & 1.29 & 1.33 & 0.15 \\
\hline A. Final Wgt. (kg/bird) & 1.42 & 1.46 & 1.36 & 1.34 & 1.39 & 1.37 & 0.17 \\
\hline A. Wgt. Gain (g/bird) & $0.02 \mathrm{bc}$ & $0.09 a$ & $0.02 \mathrm{bc}$ & $0.00 \mathrm{c}$ & $0.10 \mathrm{a}$ & $0.04 \mathrm{~b}$ & 0.15 \\
\hline A. Feed Intake (g/ bird) & $107.57 \mathrm{~b}$ & $108.70 \mathrm{a}$ & $108.67 \mathrm{a}$ & $104.06 \mathrm{bc}$ & $102.71 \mathrm{c}$ & $104.88 \mathrm{bc}$ & 10.05 \\
\hline FCR & $0.29 \mathrm{c}$ & $0.07 b$ & $0.37 \mathrm{c}$ & $0.52 \mathrm{~d}$ & $0.07 \mathrm{~b}$ & $0.02 \mathrm{a}$ & 0.07 \\
\hline HDP (\%) & $65.00 \mathrm{a}$ & $64.52 \mathrm{ab}$ & $64.56 \mathrm{ab}$ & $56.54 \mathrm{c}$ & $59.75 b$ & $53.04 \mathrm{c}$ & 17.53 \\
\hline Mort. (\%) & 0 & 3.33 & 0.33 & 1.67 & 1.67 & 1.67 & - \\
\hline
\end{tabular}

$a, b, c$ means on the same row with different superscript are significantly different $(p<0.05)$, A.: Average, FCR: Feed Conversion Ratio, HDP: Hen Day Production, Mort:: Mortality, kg: kilogram, g: gram

Table 3: Haematology of laying hens fed varied inclusion levels of ginger and garlic.

\begin{tabular}{|c|c|c|c|c|c|c|c|}
\hline Parameters & Diet 1 & Diet 2 & Diet 3 & Diet 4 & Diet 5 & Diet 6 & SEM ( \pm$)$ \\
\hline PCV $(\% 0$ & $30.20 \mathrm{c}$ & $32.10 \mathrm{~b}$ & $34.10 \mathrm{ab}$ & $34.47 a$ & 34.17ab & $34.59 \mathrm{a}$ & 0.72 \\
\hline $\mathrm{RBC}(106 / \mu \mathrm{m})$ & $2.27 \mathrm{~d}$ & $2.84 \mathrm{c}$ & $3.27 \mathrm{~b}$ & $3.48 \mathrm{a}$ & $3.67 a b$ & $3.66 a$ & 0.22 \\
\hline WBC (mg/dl) & $3.85 b c$ & $4.79 b c$ & $6.16 \mathrm{~b}$ & $7.58 \mathrm{ab}$ & $7.70 \mathrm{ab}$ & $8.36 \mathrm{a}$ & 0.73 \\
\hline MCV (\%) & $134.00 \mathrm{ab}$ & $128.17 \mathrm{c}$ & $117.67 \mathrm{~d}$ & $139.17 b$ & $149.50 \mathrm{ab}$ & $155.83 a$ & 5.7 \\
\hline MCHC (\%) & $24.17 d$ & $31.17 \mathrm{c}$ & $34.17 \mathrm{~b}$ & $34.83 \mathrm{ab}$ & $34.62 \mathrm{ab}$ & 46.33a & 2.93 \\
\hline $\mathrm{Hb}(\mathrm{g} / \mathrm{dl})$ & $21.83 d$ & $25.83 c$ & $26.00 \mathrm{bc}$ & $27.00 \mathrm{bc}$ & $28.17 b$ & $41.83 a$ & 2.82 \\
\hline
\end{tabular}

$a, b, c$ means on the same row with different superscript are significantly different $(p<0.05)$, PCV: Packed cell Volume, RBC: Red Blood Cell, WBC: White Blood Cell, MCV: Mean Cell Volume, MCHC: Mean Corpuscular Haemoglobin Concentration, Hb: Haemoglobin. 
Table 4 shows the serum biochemical indices were all significantly influenced except cholesterol. $\mathrm{T}_{6}$ recorded highest statistical values in all parameters for Total protein, $(4.37 \mathrm{~g} / 100 \mathrm{ml})$, globulin $(3.33 \mathrm{~g} / 100 \mathrm{ml})$, creatine $(1.76 \mathrm{~g} / 100 \mathrm{ml})$, calcium $(14.67 \mathrm{mg} / 100 \mathrm{ml})$, magnesium $(5.18 \mathrm{mg} / 100 \mathrm{ml})$, and potassium $(35.12 \mathrm{mg} / 100 \mathrm{ml})$ while the lowest mean values was recorded by $\mathrm{T}_{1}(0 \%$ inclusion of ginger and garlic) with values of $1.24 \mathrm{~g} / 100 \mathrm{ml}$,
$1.12 \mathrm{~g} / 100 \mathrm{ml}, 10.87 \mathrm{mg} / 100 \mathrm{ml}, 2.06 \mathrm{mg} / 100 \mathrm{ml}, 25.03 \mathrm{mg} / 100 \mathrm{ml}$ for Total protein, creatine, calcium, magnesium and potassium respectively. $\mathrm{T}_{2}$ shows the lowest value of globulin $(0.71 \mathrm{~g} / 100 \mathrm{ml})$. $\mathrm{T}_{5}$ and $\mathrm{T}_{6}$ recorded no cholesterol compared to the rest of the treatment with $0 \%$ inclusion and combined inclusion with values of $0.10 \mathrm{mg} / 100 \mathrm{ml}$ numerically.

Table 4: Serum biochemical indices of laying hens fed varied inclusion levels of ginger and garlic.

\begin{tabular}{|c|c|c|c|c|c|c|c|}
\hline Parameters & Diet 1 & Diet 2 & Diet 3 & Diet 4 & Diet 5 & Diet 6 & SEM ( \pm$)$ \\
\hline Total Protein $(\mathrm{g} / 100 \mathrm{ml})$ & $1.24 \mathrm{~d}$ & $1.44 \mathrm{c}$ & $1.76 \mathrm{c}$ & $2.97 \mathrm{bc}$ & $3.80 \mathrm{~b}$ & $4.37 \mathrm{a}$ & 0.54 \\
\hline Globulin (g/100ml) & $0.83 c$ & $0.71 \mathrm{~d}$ & $0.93 c$ & $1.66 \mathrm{bc}$ & $2.05 \mathrm{~b}$ & $3.33 a$ & 0.41 \\
\hline Cholesterol (mg/100ml) & 0.1 & 0.1 & 0.1 & 0.1 & 0 & 0 & 0 \\
\hline Creatine (mg/100ml) & $1.12 \mathrm{~d}$ & $1.27 \mathrm{bc}$ & $1.24 \mathrm{c}$ & $1.28 \mathrm{bc}$ & $1.43 \mathrm{~b}$ & $1.76 \mathrm{a}$ & 0.91 \\
\hline Calcium (mg/100ml) & $10.87 d$ & $11.91 \mathrm{bc}$ & $12.70 \mathrm{c}$ & $13.47 \mathrm{ab}$ & $14.13 a$ & $14.67 \mathrm{a}$ & 0.58 \\
\hline Magnesium (mg/100ml) & $2.06 \mathrm{~d}$ & $3.28 \mathrm{bc}$ & $3.86 \mathrm{c}$ & $4.40 \mathrm{ab}$ & $4.82 \mathrm{ab}$ & $5.18 \mathrm{a}$ & 0.47 \\
\hline Potassium (mg/100ml) & $25.03 c$ & $26.35 b$ & $28.42 b$ & $32.30 \mathrm{ab}$ & $34.42 \mathrm{a}$ & $35.12 \mathrm{a}$ & 1.74 \\
\hline
\end{tabular}

$a, b, c$ means on the same row with different superscript are significantly different $(p<0.05)$

\section{Discussion}

The results for the performance characteristics revealed that the combination of ginger and garlic had no significant effect on the growth performance, hence could not be used as growth promoters for laying hens at the level of inclusion used. According to [8], the inclusion of $1 \mathrm{~g} / \mathrm{kg}$ of ginger did not affect growth performance. [9] however, reported a slight improvement in the growth performance of broilers fed ginger supplements at 5, 10 and $15 \mathrm{~g} / \mathrm{kg}$ although may be useful in layers. [10] also reported that the combination of ginger and garlic significantly improved the growth of chicks than garlic and ginger as a sole agent in broiler diets. It can be inferred that the effect of garlic and ginger on the growth performance of poultry (broiler and layer) is dependent on its dose and preparation. The results also showed that ginger and garlic spices are highly rich in protein and other nutrients like vitamin $\mathrm{B}$ and $\mathrm{C}$, minerals in particular iron, and the sulphur containing amino acids, methionine and cysteine [11,12]. Feed intake and feed conversion ratio had highest significant differences from the experiment carried out because there was little influence on the laying hens fed ginger and garlic as sole agent and 1\% ginger and $1 \%$ garlic inclusions compared to the control which agrees with [13]. Also, they found that daily feed intake and FCR did not differ between laying hens fed ginger in the diet $(5,10,15$ and $20 \mathrm{~g} / \mathrm{kg}$ ) and [14] found that feeding ginger at different levels of $(.25 \%, 0.5 \%$ and $0.75 \%)$ had no effect on feed intake and feed conversion ratio in laying hens. There were significant differences in the hen day production with $0 \%$ inclusion of both ginger and garlic having better performance than inclusions of combined ginger and garlic and as sole agent; however, this is in not line with [13] who reported that laying hens fed with ginger at the rates of 5 , 10,15 and $20 \mathrm{~g} / \mathrm{kg}$ of feed had no effect on laying rate and average egg weight. The results of haematological indices showed that the PCV of the birds across the treatments ranged between $30.20 \%$ and $34.59 \%$ which followed a specific trend. The normal range for normal adult chicken reported by [15] was 30-40\%. Hence, the values obtained could be considered normal. The concentration of haemoglobin obtained ranged between $21.83 \mathrm{~g} / \mathrm{dl}$ and $41.83 \mathrm{~g} /$ dl which could be considered not normal when compared to the normal physiological range of $9-13 \mathrm{~g} / \mathrm{dl}$ reported by [15]. WBC counts had significant influences across all treatments, which implies that the experimental diets at the levels of inclusion could not be tolerated without compromising the welfare or immunity of the birds. The MCV and MCHC of the hens were not on the reported range of $127 \%$ and $29 \%$ respectively because they were all above the values reported by [15]. There were no significant differences in the cholesterol, and this agrees with the study conducted by $[16,17]$ where garlic was effective in lowering the total cholesterol via its effect on the plasma concentration of LDL cholesterol.

\section{Conclusion}

It could be concluded that the combination of garlic and ginger do not enhance growth performance, and such cannot be used as growth promoters in layers. The hematology and serum parameters revealed there is no toxicity associated with the consumption of ginger and garlic combination or as sole agents at the inclusion levels considered. The combined effect of the spices has greater influence as an anti-hypercholesterolemia agent. Based on the results, it can, therefore, be recommended that laying hens can be fed combination of ginger and garlic below 3\% inclusions without detrimental effects on the overall performance and health implications of the birds.

\section{Authors' Contributions}

JAO designed plan of study and supervised the research trial, whereas OMA analyzed collected data and wrote the manuscript. OMA and GOA was the principal author who was responsible to 
manage all activities of the experiment and worked in the execution of trial and also involved in data collection and interpretation. All authors read and approved the final manuscript.

\section{Acknowledgement}

Not applicable.

\section{Conflict of Interest}

No conflict of interest.

\section{References}

1. Aletor VA, Hamid II, Niess E, Pfeitter E (2000) Low protein amino acids supplemented diets in sources by broiler starter chicks. J Sci Food Agric 80: $547-554$.

2. Herawati, Marjuki (2011) The effect of feeding red ginger (Zingiber officinale Roscoe) as phytobiotics on broiler slaughter weight and meat quality. Int J Poult Sci 10: 983-985.

3. Oyekunle MA, Owonikoko MO (2002) Antimicrobial drug usage for poultry production within a local government area in Ogun state. Nig J Anim Prod 29(1): 113-120.

4. Keith R (2001) Could environment play a role in Alzheimer's diseases? Newsline Alabama Cooperative Extension System Nutritionist. 334-844.

5. Al Homidan AA (2005) Efficacy of using different sources and levels of Allium sativum and Zingiber officinale on broiler chick's performance. Sau J Bio Sci 12: 96-102.

6. Duncan DB (1955) Multiple ranges and Multiple F test biometrics. International Biometric Society 11(1): 1-42

7. Ewuola EO, Folayan OA, Gbore FA, Adebunmi AI, Akanji RA, et al. (2004) Physiological response of growing West African goats fed groundnut shell-based diets as the concentrate supplement. Int J Anim Sci 6: 25-34.
8. El Deeks AA, Attia YA, Maysa M, Hannfy M (2002) Effect of anise (Pimpinella anisum), ginger (Zingiber officinale Roscoe), and fennel (Foeniculum vulgare) and their mixture on performance of broilers. Arch Gefl 67: 92-96.

9. Farinu GO, Ademola SG, Ajayi A, Babatunde GM (2004) Growth, performance and biochemical studies on garlic and ginger fed broiler chickens. Moor J Agric Res 5: 122-128.

10. Ademola SG, Farinu GO, Babatunde GM (2009) Serum lipids, growth and haematological parameters of broiler fed garlic, ginger and their mixtures. World J Agric Sci 5(1): 99-104.

11. Makkar HPS, Becker K (1999) Plants toxins and detoxification methods to improve feed quality of tropical seeds review. Asian-Australian J of Anim Sci 3: 467-480.

12. Francis G, Makkar HPS, Becker K (2005) Products from little research plants as aquaculture feed ingredients. In t Anim Sci 23(1): 23-35.

13. Zhao X, Yang ZB, Yang WR, Wang Y, Jiang SZ (2011) Effects of ginger root (Zingiber officinale) on laying performance and antioxidant status of laying hens and on dietary oxidation stability. Poult Sci 90(8): 17201727.

14. Akbarian A, Abolghasen G, Ahmadi S, Hossein M (2011) Effects of ginger root on egg yolk cholesterol, antioxidant status and performance of laying hens. J App Anim Sci 39(1): 19-21.

15. Mitruka BM, Rawnsley HM (1977) Clinical biochemical and haematological reference values in normal experimental animals. Masson Publishing USA Inc, USA, pp. 46-47.

16. Prasad R, Rose MK, Virmani M, Garg SL, Puri JP (2009) Lipid profile of chicken (Gallus domesticus) in response to dietary supplementation of garlic (Allium sativum). Int J Poult Sci 8: 270-276.

17. Yeh YY, Liu L (2001) Cholesterol-lowering effect of garlic extracts and organosulfur compounds: Human and animal studies. J Nutr 131(3s): 989S-993S 